\title{
SYNOPSIS OF THE WOODY SPECIES OF SMILAX IN THE EASTERN UNITED STATES NORTH OF PENINSULAR FLORIDA
}

\author{
A. J. BULLARD
}

307 Henderson Street, Mt. Olive, NC 28365

CHARLES M. ALLEN

Colo. State University, Fort Polk Station, 1645 23rd Street, Fort Polk, LA 71459

\begin{abstract}
The nine woody species of Smilax (S. auriculata, S. bona-nox, S. glauca, S. laurifolia, $S$. pumila, S. rotundifolia, $S$. smallii, $S$. tamnoides, and $S$. walteri) of the eastern United States north of peninsular Florida are described through the use of charts. The habitat, range, common names, and synonyms for each are listed. A key to the nine species is provided.
\end{abstract}

Key Words: Smallii; key; chart; species.

\section{INTRODUCTION}

The genus Smilax L. includes herbaceous species (Section Coprosmanthus (Torrey) Bentham syn = Nemexia (Rafenisque) A. de Candolle) and woody species (Section Smilax). The genus was traditionally included in the Liliaceae but is now in its own family, Smilacaceae. In the eastern United States, the genus Smilax includes nine woody species; $S$. auriculata Walter, S. bona-nox L., S. glauca Walter, S. laurifolia L., S. pumila Walter, S. rotundifolia L., S. smallii Morong, S. tamnoides L., and S. walteri Pursh. We recognize these nine species plus two varieties of $S$. bonanox; var. bona-nox and var. littorale Coker.

All species of Smilax are included by Holmes (2002) in the Flora of North America treatment (Flora of North America Editorial Committee 2002). All woody species of Smilax were covered by Coker (1944) and the woody species of the southeastern United States by Duncan (1967). All Smilax species were included in Judd's 1998, treatment of the Smilacaceae in the southeastern United States. Diggs et al. (2006) included all but $S$. auriculata in their work on monocots of east Texas and Allen et al. (2002) included all nine species in their work on woody plants of Louisiana. All nine species within the range is available on-line from the USDA Plant Database (USDA NRCS 2011). Yates and Duncan (1970) included all the woody species of Smilax except for $S$. pumila in their leaf anatomical work. Other anatomical works include Arber (1920); Caponetti and Quimby (1956); and Martin and Tucker (1985). Our data are based on the aforementioned publications plus field observations by both authors for more than $30 \mathrm{yrs}$. and from notes taken from living specimens in the Bullard garden in North Carolina. This paper presents: (1) unreported observations, (2) brings together published data, (3) a key, charts, and descriptions to facilitate the identification of the woody species of the genus Smilax in the eastern United States north of peninsular Florida.

\section{DESCRIPTION OF SMILAX SECTION SMILAX}

Perennial, woody vines or rarely shrubs; rhizomes tuberous or stoloniferous; roots filiform. Stems climbing via tendrils, or rarely sprawling, simple or branching, armed with prickles, rarely unarmed . Leaves deciduous to evergreen, alternate; stipules present, modified to form tendrils; tendrils, paired, originating from petioles; blades linear, oblong, or ovate, base sometimes lobed. Inflorescences umbellate, axillary to leaves, loose to dense, pedunculate. Flowers unisexual; tepals 6, greenish, yellow, or bronze, ovate to elliptic; staminate flowers sometimes with pistillode, stamens 6 , anthers basifixed, dehiscence introrse; pistillate flowers with 6 staminodes, style short or absent, stigmas 3, recurved, ligulate. Fruits are berries. Berries black, blue, purple, red, or orange. $x=13-16$. The growth pattern in the woody smilaxes is serial and not secondary.

Key to the Species of Woody Smilax of the Eastern United States North of Peninsular Florida

A. Stems tomentose, lacking prickles; petioles tomentose; leaves densely tomentose beneath; berries red and with an acute tip; plant prostrate to sprawling, mostly $0.5 \mathrm{~m}$ or shorter ..... S. pumila

A. Stems glabrous to stellate-scurfy, usually with prickles; petioles glabrous; leaves glabrous or papillate beneath; berries black or dark blue or if red, then lacking a pointed tip; plant climbing, ascending, or rarely sprawling, mature plants taller than $0.5 \mathrm{~m} \ldots \ldots \ldots \ldots \ldots \ldots \ldots$ 
Table 1. Chart of the habitat characteristics of the nine woody species of Smilax in the eastern United States north of peninsular Florida.

\begin{tabular}{lllc}
\hline \multicolumn{1}{c}{ Species } & Wetland Ranking(s) & \multicolumn{1}{c}{ Sunlight } & Elevation/m \\
\hline S. auriculata & FACU & full sun to partial shade & $0-100$ \\
S. bona-nox & FACU, FACU+, FAC & full to partial sun & $0-1,000$ \\
S. glauca & UPL, FAC, FACU & full sun to partial shade & $0-800$ \\
S. laurifolia & FACW, OBL & full sun to shade & $0-400$ \\
S. pumila & NONE & full sun to shade & $0-800$ \\
S. rotundifolia & FAC & full sun to shade & $0-1,000$ \\
S. smallii & FACU, FAC & full sun to partial shade & $0-600$ \\
S. tamnoides & FAC, FAC+ & full sun to partial shade & $0-400$ \\
S. walteri & OBL & full sun to moderate shade & $0-350$ \\
\hline
\end{tabular}

B(A). Prickles abundant, thin and needle-like, black; blade veins distinctly reticulate on lower surface; blades drying to a light olive gray color; petiole $1 \mathrm{~cm}$ or longer ...S. tamnoides

B. Prickles of the stem fewer, broad-based and awl-like or catclaw-like, green, brown, or black; blade veins not distinctly reticulate on lower surface; blades drying to green or brown; petioles mostly shorter than $1 \mathrm{~cm}$. . . C

C(B). Leaves evergreen; blades mostly elliptic to linear or narrowly ovate; stem diameter $2 \mathrm{~cm}$ or larger; plant climbing to $20 \mathrm{~m}$ or higher; plants flowering in August; berries requiring two years for maturity . . . . . . . . . . . D

C. Leaves deciduous to tardily deciduous (evergreen in S. auriculata); blades mostly broadly ovate; stem diameter smaller than $2 \mathrm{~cm}$; plant climbing to $10 \mathrm{~m}$ or lower (to $20 \mathrm{~m}$ in $S$. bona-nox); plants flowering April to July; berries maturing in one year . . . . . . . . . . . . . . . E

$\mathrm{D}(\mathrm{C})$. Blades mostly oblong, thick with three veins at base, not reticulate, not varigated; petiole green to pink; blade margins without enations; berry with pointed tip . . S. laurifolia

D. Blades mostly elliptic, thin, with five veins at base, distinctly reticulate; sometimes varigated; petiole green; blade margins often with enations; berry lacking pointed tip . . . . S.smallii

$\mathrm{E}(\mathrm{C})$. Leaves evergreen, often ascending; blades thick; plants of coastal habitats .....S. auriculata

E. Leaves deciduous, rarely evergreen, not ascend ing; blades thin; plants of mostly inland habitats. . . F F(E). Berry red; petiole red; number of seeds two or more; plants of wet habitats ......S. walteri

F.Berry black to dark blue, not red; petiole green (sometimnes pink in $S$. glauca); number of seeds one to three; plants of dry to wet habitats.... . G

$\mathrm{G}(\mathrm{F})$. Blades distinctly glaucous abaxially; plants with tubers; peduncles terete. . . . . . . S. glauca

G. Blades green on abaxial surface, not glaucous; plants with rhizomes; peduncles flattened . . . . H

$\mathrm{H}(\mathrm{G})$. Prickles at internodes only; no cowhorn prickles present; blades not varigated, average thickness; peduncles longer than $1.5 \mathrm{~cm}$, twice as long as petiole; blade margins with enations; berry one seeded, not persistent; plant climbing to $6 \mathrm{~m} \ldots \ldots \ldots \ldots \ldots$. . rotundifolia

H. Prickles at internodes and nodes; cowhorn prickles present; blades sometimes varigated, thick; peduncles shorter than $1.5 \mathrm{~cm}$, as long as or shorter than petiole; blade margins lacking enations; berry $1-3$ seeded, persistent; plant high climbing to $20 \mathrm{~m}$......S. bona-nox

Characteristics of the Woody Species of Smilax of the Eastern United States North of Peninsular Florida

1. Smilax auriculata Walter, Fl. Carol. 245. 1788. (S. beyrichii Kunth; S. lata Small). Common names include wild-bamboo, earleaf greenbrier, beach greenbrier, bamboo vine, horse brier, and arrow leaf smilax. Habitats are dunes and sandy flatwoods. Reported range is Ala., Fla., Ga., La., Miss., N.C., S.C.; West Indies (Bahamas) (also reported from Arkansas by USDA, NRCS 2011).

2. Smilax bona-nox L. Sp. P1. 2: 1030. 1753 (as bona nox). (S. bona-nox L. var. exauriculata Fernald, var. hastata (Willd.) A. DC., var. hederifolia (Bey.) Fernald, S. hastata Willdenow, S. hederifolia Beyrich ex Kunth, $S$. renifolia Small, S. variegata Walter). Common names include saw greenbrier, zarzaparrilla, green brier, China brier, tramp's trouble, stretch berry, fringed green brier, cat brier, and bull brier. Habitats are well-drained to wet areas in woods, fields, thickets, hedgerows, and floodplain forests. Reported range is AL, AR, D.C., DE, FL, GA, IL, IN, KS, KY, LA, MD, MO, MS, NC, OH, OK, SC, TN, TX, VA, Mexico, and West Indies. The var. littorale Coker differs in having glabrous (non-prickly) tubers and rhizomes and lacks the scurfy texture in the lower 2-3 ft $(0.6-0.9 \mathrm{~m})$ of the stem. Coker (1944) reports it in maritime habitats from NC to FL but we report it from 
Bullard and Allen: Synopsis of Smilax In the Eastern United States

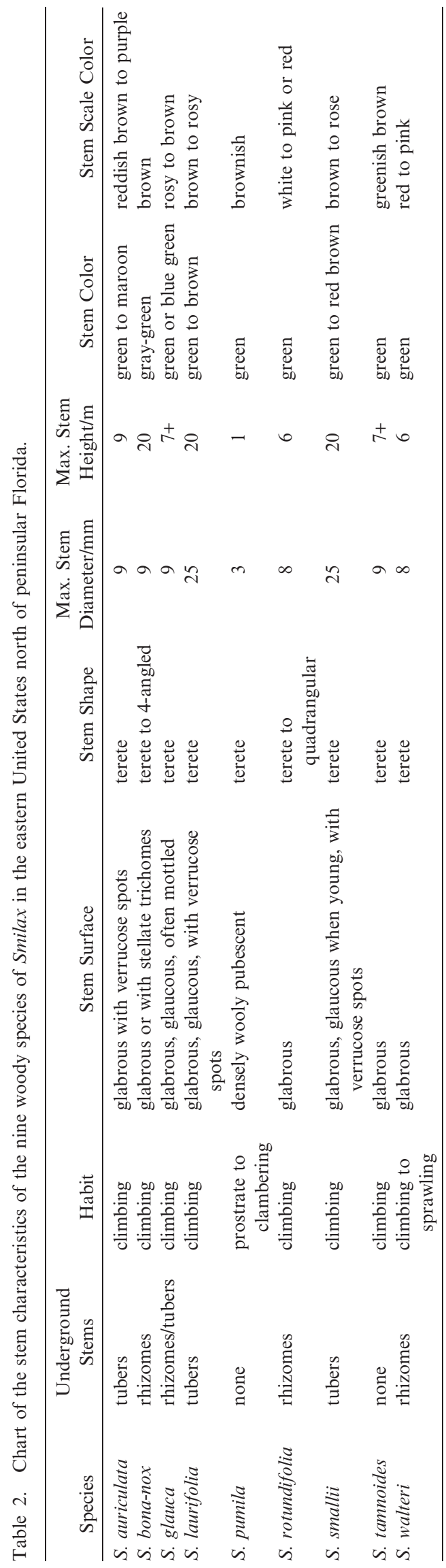

Wayne County, NC in Neuse River Basin, ca. $160 \mathrm{~km}$ from the North Carolina coast.

3. Smilax glauca Walter, Fl. Carol. 245. 1788. (S. glauca var. leurophylla S. F. Blake; S. spinulosa Smith). Common names include saw green brier, glaucous leafed green brier, sarsaparilla, wild sarsaparilla, sawbrier, and sow brier. Habitats are dry to wet woods, thickets, hedgerows, and roadsides. Reported range is $\mathrm{AL}$, AR, CT, DC, DE, FL, GA, IL, IN, KS, KY, LA, MA, MD, MO, MS, NC, NE, NJ, NY, $\mathrm{OH}, \mathrm{OK}, \mathrm{PA}, \mathrm{RI}, \mathrm{SC}, \mathrm{TN}, \mathrm{TX}, \mathrm{VA}, \mathrm{WV}$, and WY.

4. Smilax laurifolia Linnaeus, Sp. Pl. 2: 1030. 1753. (S. alba Pursh; S. lanceolata L.) Common names include lowland bamboo vine, bamboo vine, blaspheme vine, laurel greenbrier, China brier, bay leaf smilax, laurel brier, and bamboo vine. Habitats are bays, bogs, pocosins, baygalls, swamp margins, and marshy banks. Range is $\mathrm{AL}, \mathrm{AR}, \mathrm{DE}, \mathrm{FL}, \mathrm{GA}, \mathrm{LA}, \mathrm{MD}$, MS, NC, NJ, OK, SC, TN, TX, and VA. West Indies (Bahamas, Cuba).

5. Smilax pumila Walter, Fl. Carol. 244. 1788. (S. humilis Miller, name proposed for rejection; $S$. pubera Michaux; S. puberula Kunth). Habitats are woods, along streams, and sandy soil. Common names include sarsaparilla, dwarf green brier, hairy green brier, prostrate green brier, brier vine, ground brier, wild sarsaparilla, and sarsaparilla. Range is AL, AR, FL, GA, LA, MS, SC, and TX.

6. Smilax rotundifolia Linnaeus, Sp. Pl. 2: 1030. 1753. (S. caduca Linnaeus; S. quadrangularis Muhlenberg ex Willdenow; $S$. rotundifolia var. crenulata Small \& A. Heller; S. rotundifolia var. quadrangularis (Muhlenberg ex Willdenow) Alph. Wood) Habitats are dry to moist, sometimes riparian woods, borders, hedgerows, and thickets. Common names include common greenbrier, common catbrier, bullbrier, horsebrier, sow brier, hungry vine, bread and butter, devil's hop vine, bamboo brier, wait-a-bit, biscuit leaves, and roundleaf greenbrier. Range is $\mathrm{AL}, \mathrm{AR}, \mathrm{CT}, \mathrm{DC}, \mathrm{DE}, \mathrm{FL}, \mathrm{GA}, \mathrm{IA}, \mathrm{IL}, \mathrm{IN}$, KS, KY, LA, MA, MD, ME, MI, MN, MO, MS, NC, NH, NJ, NY, OH, OK, PA, RI, SC, $\mathrm{SD}, \mathrm{TN}, \mathrm{TX}$, and VA, and WV.

7. Smilax smallii Morong, Bull. Torrey Bot. Club. 21: 430. 1894. ( $S$. cinnamomiifolia Small; $S$. ovata Pursh 1814, not Duhamel 1803). Common names include lanceleaf greenbrier, coral green brier, upland bamboo vine, Jackson vine, Jackson brier, bamboo vine, cantaque, and thornless smilax. Habitats are rich woods, 
Table 3. Chart of the prickle characteristics of the nine woody species of Smilax in the eastern United States north of peninsular Florida.

\begin{tabular}{|c|c|c|c|c|c|c|}
\hline Species & Location & Cowhorn & Shape & Character & Length $/ \mathrm{mm}$ & Color/Surface \\
\hline S. auriculata & nodes and internodes & no & $\begin{array}{l}\text { flattened, angled } \\
\text { downward slightly }\end{array}$ & rigid, stout & to 4 & greenish \\
\hline S. bona-nox & nodes and internodes & yes & $\begin{array}{l}\text { flattened, broad } \\
\text { based, becoming terete } \\
\text { apically with sharp tip }\end{array}$ & rigid, stout & $4-9$ & $\begin{array}{l}\text { body brown \& scurfy tip } \\
\text { black }\end{array}$ \\
\hline S. glauca & nodes and internodes & yes & slender, slightly recurved & thin to stout & $1-5$ & dark brown \\
\hline S. laurifolia & nodes and internodes & no & flat to almost terete & rigid & to 12 & dark brown \\
\hline S. pumila* & & & & & & \\
\hline S. rotundifolia & internodes only & no & flattened & stout & to 12 & green with dark brown tips \\
\hline S. smallii & nodes and internodes & no & flattened, recurved & rigid & to 12 & brown to greenish \\
\hline S. tamnoides & nodes and internodes & no & $\begin{array}{l}\text { two kinds: bristly, slightly } \\
\text { recurved }\end{array}$ & rigid, flexible & $8-10,2-3$ & blackish, light color \\
\hline S. walteri & nodes and internodes & no & slightly recurved & subulate & to 5 & $\begin{array}{l}\text { rose colored with dark } \\
\text { brown tip }\end{array}$ \\
\hline
\end{tabular}

* Not applicable.

pinewoods, streambanks, edges of fields, swamp margins, ditches, in well-drained to dry soil. Range is AL, AR, D.C., DE, FL, GA, LA, MD, MS, NC, OK, SC, TX, and VA. Puerto Rico.

8. Smilax tamnoides Linnaeus, Sp. Pl. 2: 1030. 1753. (S. grandifolia Buckley; S. hispida Muhlenberg ex Torrey; S. hispida var. australis Small; S. hispida var. montana Coker; S. tamnoides var. hispida (Muhlenberg ex Torrey) Fernald). Common names include China root, hellfetter, bristly greenbrier, hag brier, devil green brier, and wild sarsaparilla. Habitats are wet to dry woods, thickets, and bottomlands. Range is AL, AR, CT, DC, DE, FL, GA, IA, IL, IN, KS, KY, LA, MA, MD, MI, MN, MO, MS, NC, NE, NH, NJ, NY, OH, OK, PA, SC, SD, TN, TX, VA, VT, WV, and WV. CAN (ON)

9. Smilax walteri Pursh, Fl. Amer. Sept. 1: 249. 1814. Common names include red-berried greenbrier, red-berried bamboo, coral greenbrier, redberry bamboo, sarsaparilla, redbead greenbrier. Habitats are wet thickets, low pinelands, swamps, baygalls, and boggy areas. Range is AL, AR, DE, FL, GA, LA, MD, MS, NC, NJ, SC, TN, TX, and VA.

\section{DISCUSSION}

The wettest habitat species is $S$. walteri and the dryest species are: $S$. glauca and $S$. pumila (Table 1). Species with the greatest shade tolerance are $S$. pumila, $S$. rotundifolia, and $S$. laurifolia. Lowest elevation species is $S$. auriculata and the two highest elevation species are $S$. bona-nox and $S$. rotundifolia. The four species with tubers are $S$. auriculata, $S$. glauca, $S$. laurifolia, and $S$. smallii (Table 2). One species with both a pubescent stem and also a prostrate stem is $S$. pumila. Smilax laurifolia and $S$. smalli have the largest diameter stems while $S$. pumila has the smallest. Highest climbing species are $S$. bona-nox, S. laurifolia, and $S$. smallii and the lowest climbing is $S$. pumila. The only species with prickles only at the internodes is $S$. rotundifolia; all other species with prickles have them at the nodes and internodes (Table 3 ). Cowhorn type prickles are only found in S. bona-nox and $S$. glauca. Four evergreen species are $S$. auriculata, $S$. laurifolia, S. pumila, and S. smallii (Table 4). Species with erect or ascending leaves are $S$. auriculata, S. laurifolia, and $S$. smallii (branches cascade downward). Longest petioles are found in the leaves of $S$. tamnoides and the shortest in $S$. pumila. Petiole is non-green (red to pink) in $S$. laurifolia, S. rotundifolia, and $S$. walteri and sometimes

Table 4. Chart of the leaf characteristics of the nine woody species of Smilax in the eastern United States north of peninsular Florida.

\begin{tabular}{|c|c|c|c|c|}
\hline Species & Leaves & Leaves & Petiole Length/cm & Petiole Color \\
\hline S. auriculata & evergreen & often ascending & $0.5-1.2$ & green \\
\hline S. bona-nox & evergreen to tardily deciduous & don't ascend & $0.7-1.5$ & green \\
\hline S. glauca & deciduous to evergreen & don't ascend & $0.5-1.5$ & $\begin{array}{l}\text { green (pinkish on sun } \\
\text { exposed plants) }\end{array}$ \\
\hline S. laurifolia & evergreen & often erect & $0.5-1.5$ & sometimes pink \\
\hline S. pumila & evergreen & don't ascend & $\begin{array}{c}0.05-0.25 \\
\text { (often longer on } \\
\text { sterile shoots) }\end{array}$ & green \\
\hline S. rotundifolia & deciduous to semievergreen & don't ascend & $0.5-1.5$ & pinkish \\
\hline S. smallii & evergreen & branches cascadedown, leaves ascend & $0.3-1.3$ & green \\
\hline S. tamnoides & deciduous to semievergreen & don't ascend & $1-2$ & green \\
\hline S. walteri & deciduous to semievergreen & don't ascend & $0.5-1$ & red \\
\hline
\end{tabular}


Table 5. Chart of leaf blade characteristics (shape, veins, thickness, size, and surface) of the nine woody species of Smilax in the eastern United States north of peninsular Florida.

\begin{tabular}{|c|c|c|c|c|c|c|}
\hline Species & Shape & Veins & Thickness & Length/cm & Width/cm & Surface \\
\hline S. auriculata & $\begin{array}{l}\text { narrowly ovate to } \\
\text { ovate-elliptic }\end{array}$ & $\begin{array}{l}\text { three prominent, } \\
\text { secondary obscure to } \\
\text { prominent }\end{array}$ & very thick & $4.5-6(-8.5)$ & $2-3.5$ & $\begin{array}{l}\text { not glaucous, glabrous or } \\
\text { minutely pubescent } \\
\text { abaxially }\end{array}$ \\
\hline S. bona-nox & $\begin{array}{l}\text { broadly ovate to } \\
\text { lanceolate-ovate or } \\
\text { hastate to pandurate, } \\
\text { conduplicate }\end{array}$ & $\begin{array}{l}\text { three }(-5) \text { plus or } \\
\text { minus prominent }\end{array}$ & thick & $3-10$ & $2.5-9$ & $*$ \\
\hline S. glauca & $\begin{array}{l}\text { broadly ovate, elliptic to } \\
\text { reniform }\end{array}$ & $\begin{array}{l}\text { three or five, } \\
\text { conspicuous, } \\
\text { palmate raised on } \\
\text { undersurface, some } \\
\text { reddish }\end{array}$ & average & $4.5-11$ & $2.5-6.6$ & $\begin{array}{l}\text { glabrous and glaucous } \\
\text { abaxially }\end{array}$ \\
\hline S. laurifolia & $\begin{array}{l}\text { oblong-elliptic, lance- } \\
\text { elliptic or linear or } \\
\text { broadly ovate }\end{array}$ & $\begin{array}{l}\text { three veined from } \\
\text { not prominently } \\
\text { reticulate, }{ }^{* *} \text { base, }\end{array}$ & thick & $7-13$ & $1.3-4(6)$ & coriaceous, ${ }^{*}$ \\
\hline S. pumila & $\begin{array}{l}\text { obovate to ovate- } \\
\text { lanceolate }\end{array}$ & three prominent & average & $6-10.5$ & $5-8$ & $\begin{array}{l}\text { glabrous adaxially densely } \\
\text { puberulent abaxially }\end{array}$ \\
\hline S. rotundifolia & ovate to broadly ovate & $\begin{array}{l}\text { three or five } \pm \\
\text { prominent }\end{array}$ & average & $4-17$ & $4-16$ & $\begin{array}{l}\text { lustrous, not glaucous } \\
\text { glabrous abaxially }\end{array}$ \\
\hline S. smallii & $\begin{array}{l}\text { lanceolate-elliptic to } \\
\text { narrowly ovate }\end{array}$ & $\begin{array}{l}\text { prominently reticulate, } \\
\text { five-veined from base }\end{array}$ & thin & $5-6.6$ & $1.7-3$ & $\begin{array}{l}\text { abaxially glabrous, not } \\
\text { glaucous sometimes with } \\
\text { glaucous underleaf }\end{array}$ \\
\hline S. tamnoides & $\begin{array}{l}\text { ovate-lanceolate, ovate, } \\
\text { or sometimes } \\
\text { pandurate }\end{array}$ & $\begin{array}{l}\text { prominently reticulate } \\
\text { with five protruding } \\
\text { veins on lower surface }\end{array}$ & thin & $5-13$ & $3-10$ & not glaucous, $* * *$ \\
\hline S. walteri & $\begin{array}{l}\text { ovate-oblong to } \\
\text { ovate-lanceolate }\end{array}$ & three prominent & $\begin{array}{l}\text { thin to } \\
\text { average }\end{array}$ & $6-10$ & $3-7$ & $*$ \\
\hline
\end{tabular}

* Not glaucous, glabrous or minutely pubescent abaxially.

** Lower midvein raised, not palmately veined, outer two veins much nearer margin than mid-vein.

*** Glabrous to prickly on major veins abaxially.

Table 6. Chart of leaf blade characteristics (color, varigation, base, apex, and margins) of the nine woody species of Smilax in the eastern United States north of peninsular Florida.

\begin{tabular}{|c|c|c|c|c|c|c|c|}
\hline Species & Color & Varigation & Dry Color & Base & Apex & Margins & Enations \\
\hline S. auriculata & green abaxially & no or little & brownish green & $\begin{array}{l}\text { auriculate, } \\
\text { pandurate or } \\
\text { rounded* }\end{array}$ & $\begin{array}{l}\text { acute to blunt } \\
\text { but } \\
\text { mucronate }\end{array}$ & $\begin{array}{l}\text { entire, } \\
\text { revolute }\end{array}$ & no \\
\hline S. bona-nox & pale green & often & uniform tan & $\begin{array}{l}\text { cordate to } \\
\text { truncate, } \\
\text { frequently } \\
\text { lobed }\end{array}$ & $\begin{array}{l}\text { rounded to } \\
\text { short- } \\
\text { apicuate }\end{array}$ & $\begin{array}{l}\text { entire to } \\
\text { remotely } \\
\text { spinose- } \\
\text { ciliate**, }\end{array}$ & no \\
\hline S. glauca & $\begin{array}{l}\text { green to glaucous } \\
\text { green adaxially, } \\
\text { silvery grayish } \\
\text { abaxially }\end{array}$ & often adaxially & brownish tan & $\begin{array}{l}\text { truncate, } \\
\text { subcordate or } \\
\text { attenuate }\end{array}$ & $\begin{array}{l}\text { rounded, } \\
\text { tapering or } \\
\text { short- } \\
\text { acuminate }\end{array}$ & $\begin{array}{l}\text { entire, } \\
\text { revolute }\end{array}$ & no \\
\hline S. laurifolia & $\begin{array}{l}\text { green to brownish } \\
\text { green }\end{array}$ & no & pale brown & $\begin{array}{l}\text { attenuate to } \\
\text { rounded }\end{array}$ & $\begin{array}{l}\text { acute to } \\
\text { rounded, } \\
\text { often } \\
\text { mucronate }\end{array}$ & $\begin{array}{l}\text { entire, often } \\
\text { revolute }\end{array}$ & no \\
\hline S. pumila & gray-green & sometimes ashy & gray green & $\begin{array}{l}\text { cordate to } \\
\text { deeply } \\
\text { notched }\end{array}$ & $\begin{array}{l}\text { bluntly } \\
\text { pointed }\end{array}$ & entire & no \\
\hline S. rotundifolia & bright green & no & $\begin{array}{l}\text { pale to } \\
\text { brownish } \\
\text { green }\end{array}$ & $\begin{array}{l}\text { cordate to } \\
\text { rounded } \\
\text { with acute } \\
\text { insertion at } \\
\text { petiole }\end{array}$ & $\begin{array}{l}\text { abruptly } \\
\text { pointed }\end{array}$ & $\begin{array}{l}\text { entire, } \\
\text { sometimes } \\
\text { tightly } \\
\text { revolute }\end{array}$ & yes \\
\hline
\end{tabular}


Table 6. Continued

\begin{tabular}{|c|c|c|c|c|c|c|c|}
\hline Species & Color & Varigation & Dry Color & Base & Apex & Margins & Enations \\
\hline S. smallii & deep green & often & pale & green & $\begin{array}{c}\text { rounded to } \\
\text { cuneate }\end{array}$ & $\begin{array}{r}\text { acuminate } \\
\text { or acute }\end{array}$ & $\begin{array}{l}\text { entire to } \\
\text { undulate }\end{array}$ \\
\hline S. tamnoides & green & not gray & light olive & $\begin{array}{c}\text { rounded to } \\
\text { cordate }\end{array}$ & pointed & $\begin{array}{l}\text { entire } \\
\text { apically, } \\
\text { serrulate } \\
\text { basally, thin, } \\
\text { flat, not } \\
\text { banded }\end{array}$ & minutely \\
\hline S. walteri & green & no & $\begin{array}{l}\text { lightly } \\
\text { orange } \\
\text { tinted } \\
\text { brown }\end{array}$ & $\begin{array}{l}\text { rounded, or } \\
\text { sometimes* } \\
\text { acute, } \\
\text { mucronate }\end{array}$ & $\begin{array}{l}\text { entire, } \\
\text { revolute } \\
\text { with } \\
\text { enations on } \\
\text { basal } 1 / 3\end{array}$ & young & \\
\hline
\end{tabular}

* Cuneate at insertion of petiole; **thickened by ribbed, cartilaginous band, often revolute and appearing as prominent vein parallel to margins.

Table 7. Chart of the umbel characteristics of the nine woody species of Smilax in the eastern United States north of peninsular Florida.

\begin{tabular}{lllcll}
\hline \multicolumn{1}{c}{ Species } & \multicolumn{1}{c}{ Number } & \multicolumn{1}{c}{ Location } & Number of Flowers & Character & Shape \\
\hline S. auriculata & $3-8$ & terminal, axillary to leaves & $5-8(25)$ & loose & spherical \\
S. bona- nox & few to numerous & axillary to leaves & $10-15$ & moderately dense & spherical \\
S. glauca & few to many & axillary to leaves & $5-12$ & open & umbellate to hemispherical \\
S. laurifolia & numerous & axillary to leavess & $5-12(-25)$ & topen & spherical \\
S. pumila & $1-7$ & axillary to leaves & $5-16$ & loose & spherical \\
S. rotundifolia & numerous & axillary to leaves & $5-12(-20)$ & open to dense & hemispherical to spherical \\
S. smallii & many & axillary to leaves & $7-15$ & loose to dense & hemispherical to spherical \\
S. tamnoides & many & axillary to leaves & to 25 & open to dense & spherical \\
S. walteri & few to many & axillary to leaves & $5-12$ & loose & hemispherical \\
\hline
\end{tabular}

Table 8. Chart of the inflorescence and flower characteristics of the nine woody species of Smilax in the eastern United States north of peninsular Florida.

\begin{tabular}{|c|c|c|c|c|c|c|c|}
\hline Species & Peduncle Length $/ \mathrm{cm}$ & Peduncle Shape & Flower Color & $\begin{array}{l}\text { Pedicel Length } \\
(\mathrm{mm})\end{array}$ & $\begin{array}{l}\text { Tepal Length } \\
(\mathrm{mm})\end{array}$ & $\begin{array}{l}\text { Anther } \\
\text { Length }\end{array}$ & $\begin{array}{c}\text { Flower } \\
\text { Fragrance }\end{array}$ \\
\hline S. auriculata & $0.2-1.5$ & $\begin{array}{l}\text { terete chartreuse, } \\
\text { yellow-green }\end{array}$ & & $2-10$ & ○’ 6-8, ᄋ 3-4 & not measured & yes \\
\hline S. bona-nox & $\begin{array}{l}1.5-6+, 2 \mathrm{X}> \\
\text { petiole }\end{array}$ & flattened & pale green & $8-12$ & $3-4.5$ & $*$ & no \\
\hline S. glauca & $2-5$ & terete & yellow to bronze & $5-10$ & $3-7$ & $>$ filament & no \\
\hline S. laurifolia & $\begin{array}{l}0.5-1 \\
\quad(<\text { subtending } \\
\text { leaf })\end{array}$ & terete & $\begin{array}{l}\text { yellow, cream, or } \\
\text { white }\end{array}$ & $5-10$ & $4-5$ & $>$ filament & yes \\
\hline S. pumila & $0.2-0.8^{* *}$ & terete & yellowish & $1-4$ & $3-4$ & $\begin{array}{l}\text { much shorter } \\
\text { than filament }\end{array}$ & no \\
\hline S. rotundifolia & $0.5-1.5$ & flattened & $\begin{array}{l}\text { pale yellowish, } \\
\text { green to bronze }\end{array}$ & $2-15$ & $3-4$ & $*$ & no \\
\hline S. smallii & $0.5-1$ & terete & green & $3-10$ & $3-6$ & $\begin{array}{l} \pm 1 / 5 \text { as long as } \\
\text { filaments }\end{array}$ & yes \\
\hline S. tamnoides & $1.5-7$ & terete & green to bronze & $4-12$ & $4-5$ & $*$ & no \\
\hline S. walteri & $0.5-2 \mathrm{~cm}^{* * *}$ & flattened & brownish yellow & $5-10$ & $3-6$ & not measured & no \\
\hline
\end{tabular}

* Shorter than to \pm equaling filaments; **shorter than to 1.5 as long as petiole of subtending leaf; *** generally shorter than petiole of subtending leaf. 
Table 9. Chart of the fruit (berry) characteristics and flowering and fruiting times of the nine woody species of Smilax in the eastern United States north of peninsular Florida.

\begin{tabular}{|c|c|c|c|c|c|c|c|}
\hline \multirow[b]{2}{*}{ Species } & \multicolumn{5}{|c|}{ Fruit } & \multirow[b]{2}{*}{$\begin{array}{l}\text { Flowering } \\
\text { Dates }\end{array}$} & \multirow[b]{2}{*}{$\mathrm{n}$} \\
\hline & Color & Shape & $\begin{array}{l}\text { Size/ } \\
\mathrm{mm}\end{array}$ & Surface & $\begin{array}{l}\text { Number } \\
\text { Seeds }\end{array}$ & & \\
\hline S. auriculata & $\begin{array}{l}\text { purplish, maroon, } \\
\text { black, blue green }\end{array}$ & $\begin{array}{l}\text { ovoid to flattened, } \\
\text { round }\end{array}$ & $6-7$ & glaucous & $1-3$ & May-July & $\begin{array}{l}\text { October- } \\
\text { November }\end{array}$ \\
\hline S.bona-nox & black & ovoid to spherical & $6-8$ & $\begin{array}{l}\text { shiny to dull, } \\
\text { sometimes glaucous }\end{array}$ & one & mid-late April & $\begin{array}{l}\text { September- } \\
\text { November }\end{array}$ \\
\hline S. glauca & blue to black & subglobose & $8-10$ & shiny, glaucous & $1-3$ & mid-late April & $\begin{array}{l}\text { September- } \\
\quad \text { November } *\end{array}$ \\
\hline S. laurifolia & black & $\begin{array}{l}\text { void, oblong with } \\
\text { pointed tip }\end{array}$ & $5-8$ & shiny, glaucous & one & August & $\begin{array}{l}\text { September- } \\
\text { October } * *\end{array}$ \\
\hline S. pumila & brownish orange & ovoid, acute beaks & $5-8$ & not glaucous & one & $\begin{array}{l}\text { October- } \\
\text { November }\end{array}$ & April-May \\
\hline S. rotundifolia & blue-black to black & globose, round & $5-8$ & glaucous & $1-3$ & mid-late April & $\begin{array}{l}\text { September- } \\
\quad \text { November } *\end{array}$ \\
\hline S. smallii & black & $\begin{array}{l}\text { globose to } \\
\text { compressed, } \\
\text { immature fruits = } \\
\text { round }\end{array}$ & $5.5-8$ & glaucous & $1-3$ & August & July-August ** \\
\hline S. tamnoides & black, green black & $\begin{array}{l}\text { globose, ellipsoid, } \\
\text { almost round }\end{array}$ & $6-10$ & not glaucous & $1-2$ & April-May & $\begin{array}{l}\text { September- } \\
\quad \text { November * }\end{array}$ \\
\hline S. walteri & bright red & globose & $7-9$ & shiny & $2-4$ & mid-late April & $\begin{array}{l}\text { September- } \\
\quad \text { November } *\end{array}$ \\
\hline
\end{tabular}

* Fruit persistent; ** maturing $2^{\text {nd }}$ year.

in S. glauca. The blades are narrower (elliptic) than ovate in S. laurifolia and S. smallii (Table 5). The thickest of all blades is $S$. auriculata but S. bona-nox and $S$. laurifolia have thick blades and $S$. smallii and $S$. tamnoides have the thinnest blades. Varigated blades are often found in S. bona-nox, S. glauca and S. smallii and rarely in $S$. auriculata (Table 6). Enations are found along the blade margins in $S$. rotundifolia, $S$. smallii, S. tamnoides, and $S$. walteri. Most species produce loose flowered umbels with $S$. bona-nox producing the most dense (Table 7). Longest peduncles are produced by $S$. bona-nox and $S$. tamnoides and the peduncles are flattened in S. bona-nox, S. rotundifolia, and $S$. walteri and are terete in the other species (Table 8). Berries are red to orange in $S$. pumila and $S$. walteri and have pointed tips in S.laurifolia and $S$. pumila (Table 9). Number of seeds is always two or more in S. walteri and always only one in S. bona-nox, $S$. laurifolia, and $S$. pumila. Most unusual flowering time is by $S$. pumila in October to November and both $S$. laurifolia and S. smallii flower in August. Most fruits mature in the fall but $S$. pumila's fruits mature in April to May and S. laurifolia and S. smalli's fruits require two years for maturity. Fruits are persistent in $S$. glauca, S. rotundifolia, S. tamnoides, and $S$. walteri.

\section{LITERATURE CITED}

ALlEN, C. M., D. A. NEWMAN, AND H. H. WINTERS. 2002. Trees, Shrubs, and Woody Vines of Louisiana. Allen's Native Ventures Press, Pitkin, LA. 333 p pp.

ARBER, A. 1920. Tendrils of Smilax. Bot. Gaz. 69:438-442.

CAPONETTI, J. D., AND M. W. QUIMBY. 1956. The comparative anatomy of certain species of Smilax. J. of the American Pharmaceutical Association 45(1):691-696.

COKER, W. C. 1944. The woody smilaxes of the United States. J. Elisha Mitchell Sci. Soc. 60:27-69, plates 9-39.

DIGGS, G. M., JR., B. L. LIPSCOMB, M. D. REED, AND R. H. O'KENNON. 2006. Illustrated Flora of East Texas. Vol. 1. Brit Press, Fort Worth, TX. 1594 pp.

DUNCAN, W. H. 1967. Woody Vines of the southeastern United States. Sida 3:1-76.

FLORA OF NORTH AMERICA EDITORIAL COMMITTEE. 2002. Flora of North America. Magnoliophyta: Liliidae: Liliales and Orchidales. Oxford Univ. Press, New York, NY 26:468-478.

JUDD, W. S. 1998. The Smilacaceae in the southeastern United States. Harvard Pap. Bot. 3:147-169.

MARTIN, B. F., AND S. C. TUCKER. 1985. Developmental Studies in Smilax (Liliaceae). I. Organography and the Shoot Apex. American J. of Botany 72(1):66-74.

USDA, NRCS. 2011, The PLANTS Database (http://plants.usda.gov) (15 September 2011). National Plant Data Team, Greensboro, NC 27401-4901 USA.

YATES, I. E., AND W. H. DUNCAN. 1970. Comparative studies of Smilax section Smilax of the southeastern United States. Rhodora 72(791):289-312. 